\title{
KINETICS AND MECHANISM OF BASE HYDROLYSIS OF A-AMINOACID ESTERS CATALYSED BY [Pd(1,3- DIAMINO-2-HYDROXYPROPANE)( $\left.\left.\mathrm{H}_{2} \mathrm{O}\right)_{2}\right]^{2+}$ COMPLEX
}

\author{
Al-QALAF . F. Ac , Al BASSAM. A.A . AND. SHOUKRY. M.M., \\ a) Department of Chemistry, Faculty of Science, Islamic University-Madinah, Saudi Arabia. \\ ${ }^{b)}$ Department of Chemistry, Faculty of Science, Cairo University, Giza, P.O. Box 12611, Egypt. \\ c) Deparment of Chemistry, Faculty of Snience, Public Authority for Applied Education and Training, Kuwait. \\ (Received: July 23, 2012 - Accepted: January 5, 2013)
}

\begin{abstract}
Amino acid esters $(\mathrm{L})$ react with $\left[\mathrm{Pd}\left(\mathrm{DHP}\left(\mathrm{H}_{2} \mathrm{O}\right)_{2}\right]^{2+},\left(\mathrm{DHP}=1,3\right.\right.$-diamino-2-hydroxopropane) giving mixed ligand $[\mathrm{Pd}(\mathrm{DHP}) \mathrm{L}]^{2+} \mathrm{The}$ kinetics of hydrolysis of $[\mathrm{Pd}(\mathrm{DHP}) \mathrm{L}]^{2+}$ have been studied by $\mathrm{pH}$-stat technique and rate constants were obtained. Rate acceleration observed for glycine methyl ester is high. The effect with methionine methyl ester and histidine methyl ester are much less marked, as the mixed-ligand complexes with these ligands do not involve alkoxycarbonyl donors. Possible mechanisms for these reactions are considered. Activation parameters have been determined for glycine methyl ester.

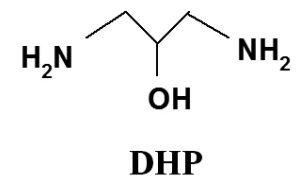

Keywords: 1,3-diamino-2-hydroxopropane, Amino acid ester hydrolysis, $\mathrm{Pd}(\mathrm{II})$, pH-stat technique.
\end{abstract}

\section{INTRODUCTION}

Metal ions in metalloenzymes such as carboxypeptidase $\mathrm{A}^{1}$, carbonic anhydrase ${ }^{2}$ and alkaline phosphatase ${ }^{3}$ play a key role in many biochemical processes. ${ }^{4}$ In these metalloenzymes, the metal ions at the active sites are considered to serve as a primary catalytic considered to serve as a primary catalytic centre for bringing substrate and nucleophile together through formation of a coordination complex, to activate the substrate carbonyl group facilitating attack of the nucleophile in caroxypeptodase $\mathrm{A}^{5}$ or to activate the water molecule in the reversible hydrated process of carbon dioxide in carbonic anhydrase $^{6}$ and to activate the serine hydroxyl group in alkaline phosphatase. In order to probe the mechanism by which the metalloenzyme may operate and consequently provide a theoretical base for designing high effective artificial metalloenzyme, previous reports ${ }^{8-11}$ have developed biomimetic models for metalloenzyme which catalyse the hydrolysis of carboxylic acid esters in biomemetic models for certain metalloenzymes, as the metalloenzymesubstrate complex .

Work in our laboratory ${ }^{12-17}$ has focused on catalysis of the hydrolysis of various amino acid esters by metal complexes. The mixed ligand complex $[\mathrm{Pd}(\mathrm{en}) \mathrm{L}]^{2+}$, where a five-membered chelate ring is formed, undergoes hydrolysis by water and hydroxide ion. ${ }^{18}$ It is therefore of considerable interest to extend this work to the mixed ligand complex with 1,3-diamino-2hydroxypropane, where a six- membered chelate ring. The increase of chelate ring size may affect the elecrophilicity of the $\mathrm{Pd}(\mathrm{II})$ ion and tune the reactivity of this metal centre in possible catalytic and biological applications as the hydrolysis of the ester group.

\section{EXPERIMENTAL}

\section{Materials and reagent}

All reagents were of Analar grade. $\mathrm{K}_{2} \mathrm{PdCl}_{4}$ and 1,3-diamine-2hydroxopropane are provided by Aldrich. The glycine-, histidine-, and methionine methyl esters were purchased from Fluka. Carbonate-free $\mathrm{NaOH}$ was prepared and standardized against potassium hydrogen phthalate solution. All solutions were prepared in deionized $\mathrm{H}_{2} \mathrm{O}$.

\section{Apparatus and measuring techniques}

$\mathrm{Pd}(\mathrm{DHP}) \mathrm{Cl}_{2}$ was prepared by dissolving $\mathrm{K}_{\mathrm{PdCl}}$ ( $\left.2.82 \mathrm{mmol}\right)$ in $10 \mathrm{ml}$ water with stirring. The clear solution of $\left[\mathrm{PdCl}_{4}\right]^{2-}$ was filtered and 1,3-diamino2-hydroxopropane $(2.82 \mathrm{mmol})$, dissolved in $10 \mathrm{ml} \mathrm{H} \mathrm{H}_{2} \mathrm{O}$ was added drop wise to the stirred solution. The $\mathrm{pH}$ was adjusted to $2-3$ by the addition of $\mathrm{HCl}$ and/or $\mathrm{NaOH}$. A yellowish -brown precipitate of $\mathrm{Pd}(\mathrm{DHP}) \mathrm{Cl}_{2}$ was formed and stirred for a further 30 minute at $50{ }^{\circ} \mathrm{C}$. After filtering off the precipitate, it was thoroughly washed with $\mathrm{H}_{2} \mathrm{O}$, ethanol and diethyl ether. A yellow powder was obtained. Anal. Calcd. for $\mathrm{C}_{3} \mathrm{H}_{10} \mathrm{~N}_{2} \mathrm{OPdCl}_{2}(267.3): \mathrm{C}, 13.6 ; \mathrm{H}, 3.7 ; \mathrm{N}, 10.5$. Found: $\mathrm{C}, 13.5 ; \mathrm{H}, 4.0 ; \mathrm{N}, 10.3 \%$.

Aqueous solutions of the diaqua form of the $\mathrm{Pd}(\mathrm{DHP}) \mathrm{Cl}_{2}$ complex were prepared in situ by the addition of slightly less than two mole equivalents of $\mathrm{AgNO}_{3}$ to a solution of a known amount of the dichloro complex and stirred over night. The white precipitate of $\mathrm{AgCl}$ that formed was filtered off using a $0.1 \mathrm{~mm}$ pore membrane filter. Great care was taken to ensure that the resulting solution was free of $\mathrm{Ag}^{+}$ion and that the dichloro complex had been converted completely into the diaqua species. The ionic strength of the solutions was adjusted to $0.1 \mathrm{M}$ with $\mathrm{NaNO}_{3}$ (Acros, p.a.)

\section{Kinetic measurements}

The kinetics of hydrolysis was monitored using a Metrohm 751 Titrino operated with the SET mode (titration to a preset end point). The titroprocessor and electrode were calibrated with standard buffer solutions according to NIST. ${ }^{19}$ Hydrolysis kinetics of glycine-, methionine-, and histidine methyl esters in the presence of $\left[\mathrm{Pd}(\mathrm{DHP})\left(\mathrm{H}_{2} \mathrm{O}\right)_{2}\right]^{2+}$ is investigated by $\mathrm{pH}$-stat technique ${ }^{20,21}$. After equilibrating a solution mixture $\left(40 \mathrm{~cm}^{3}\right)$ containing $\left[\mathrm{Pd}(\mathrm{DHP})\left(\mathrm{H}_{2} \mathrm{O}\right)_{2}\right]^{2+}$ $\left(2.5 \times 10^{-3} \mathrm{M}\right)$, ester $\left(2.5 \times 10^{-3} \mathrm{M}\right)$ and $\mathrm{NaNO}_{3}(0.1 \mathrm{M})$ at the required temperature under nitrogen flow and the $\mathrm{pH}$ was brought to the desired value by the addition of $0.05 \mathrm{M} \mathrm{NaOH}$ solution. The hydrolysis was then followed by the automatic addition of $0.05 \mathrm{M} \mathrm{NaOH}$ solution to maintain the given $\mathrm{pH}$ constant. The data fitting was performed with the OLIS KINFIT set of programs ${ }^{22}$ as described previously ${ }^{23}$. The precision of the kinetic data was estimated from plot as obtained from the OLIS program output. The accepted residual values are less than $10^{-2}$. Values of the hydroxide ion concentration were estimated from the $\mathrm{pH}$ using $\mathrm{pK}_{\mathrm{w}}=13.997$ and an activity coefficient of 0.772 was determined from the Davies equation ${ }^{24}$. At the variable temperature studies, the following values of $\mathrm{pK}$ and $\mathrm{g}$ were employed ${ }^{25}$, at $15^{\circ} \mathrm{C}(\mathrm{pK}=14.35, \mathrm{~g}=0.776)$, at $20^{\circ}$ $\mathrm{C}(\mathrm{pK}=14.16, \mathrm{~g}=0.774)$ at $25^{\circ} \mathrm{C}(\mathrm{pK}=14.00, \mathrm{~g}=0.772)$ at $30^{\circ} \mathrm{C}(\mathrm{pK}$ $=13.83, \mathrm{~g}=0.770)$, at $35^{\circ} \mathrm{C}\left(\mathrm{pK}_{\mathrm{w}}=13.68, \mathrm{~g}=0.768\right)$

\section{RESULTS AND DISCUSSION}

a-amino acid esters react with $\left[\mathrm{Pd}(\mathrm{DHP})\left(\mathrm{H}_{2} \mathrm{O}\right)_{2}\right]^{2+}$ according to the equilibrium (1). The equilibrium constant is expected to be $>>1$. This is due to the high affinity of $\mathrm{Pd}^{\mathrm{II}}$ ion to react with N-ligands ${ }^{26}$. The resulting mixedligand complexes $[\mathrm{Pd}(\mathrm{DHP}) \mathrm{L}]^{2+}\left[\mathrm{L}=\mathrm{NH}_{2} \mathrm{CH}(\mathrm{R}) \mathrm{CO}_{2} \mathrm{R}^{\prime}\right]$ undergo hydrolysis by water and hydroxide ion according to Eq. (2) and (3)

$$
\left[\mathrm{Pd}(\mathrm{DHP})\left(\mathrm{H}_{2} \mathrm{O}\right)_{2}\right]^{2+}+\mathrm{L} \rightleftharpoons[\mathrm{Pd}(\mathrm{DHP}) \mathrm{L}]^{2+}+2 \mathrm{H}_{2} \mathrm{O}
$$




$$
\begin{aligned}
& {[\mathrm{Pd}(\mathrm{DHP}) \mathrm{L}]^{2+}+\mathrm{H}_{2} \mathrm{O}} \\
& {[\mathrm{Pd}(\mathrm{DHP}) \mathrm{L}]^{2+}+\mathrm{OH}^{-} \stackrel{\mathrm{H}_{2} \mathrm{O}}{\longrightarrow}\left[\mathrm{Pd}(\mathrm{DHP}) \mathrm{L}^{+}+\mathrm{R}^{\prime} \mathrm{OH}+\mathrm{H}^{+}\right.} \\
& {\left[\mathrm{Pd}(\mathrm{DHP}) \mathrm{L}^{+}\right]^{+}+\mathrm{R}^{\prime} \mathrm{OH}}
\end{aligned}
$$

\section{Where $\mathrm{L}=\mathrm{NH}_{2} \mathrm{CH}(\mathrm{R}) \mathrm{CO}_{2} \mathrm{R}^{\prime}$ and $\grave{\mathrm{L}}=\mathrm{NH}_{2} \mathrm{CH}(\mathrm{R}) \mathrm{CO}_{2}$}

The kinetic data, the volume of base added to keep the $\mathrm{pH}$ constant versus time, could be fitted by one exponential . Various other kinetic models were tested without leading to satisfying fits of the data. The values of $k_{\text {obs }}$ (the observed first-order rate constant at constant $\mathrm{pH}$ ) were obtained. Plots of $k$ versus the hydroxide ion concentration were linear with a positive intercept The precision of the data was evidenced by the correlation coefficient $\left(\mathrm{R}^{2}\right)$, Fig. (1). The rate expression is therefore of the form Eq. $(4,5)$.

$$
\text { Rate }=k_{\text {obs }}[\operatorname{Pd}(\mathrm{DHP})(\text { ester })]
$$

$$
\mathrm{k}_{\mathrm{obs}}=\mathrm{k}_{\mathrm{o}}+\mathrm{k}_{\mathrm{OH}}[\mathrm{OH}]
$$

The term $k$ arises due to water attack on the mixed-ligand complex. Values of $k_{\mathrm{H} 2 \mathrm{O}}=k_{\mathrm{o}} / 55.5$, where $55.5 \mathrm{~mol} \mathrm{dm}^{-3}$ is the molar concentration of water, were determined from the intercept, and values of $k_{\mathrm{OH}}=\left(k_{\mathrm{obs}}-k_{\mathrm{o}}\right) /[\mathrm{OH}]$ from the slopes of the plots. The various rate constants are given in Table (1).

The linear dependence of $\mathrm{k}_{\text {obs }}$ on the $\mathrm{OH}^{-}$concentration is consistent with the direct attack of $\mathrm{OH}^{-}$ion on the coordinated ester carbonyl group. The rate acceleration denoted by the catalysis ratio $\left(\mathrm{C}=\mathrm{k}_{\mathrm{OH}} / \mathrm{k}_{\mathrm{OH}}\right.$ ester) is calculated Table 1) and found to be $2.25 \times 10^{4}$ for glycine methyl ester. Rate acceleration of this magnitude is fully consistent with the formation of mixed-ligand complex where there is a direct interaction between $\mathrm{Pd}(\mathrm{II})$ and the carbonyl group of the ester (structure I). ${ }^{13,18}$ The isolation of complex (I) is not possiple as it is not

\begin{tabular}{|c|c|c|c|}
\hline System & pH & $10^{10}\left[\mathrm{OH}^{-}\right]$ & $10^{4} k_{\text {obs }}{ }^{\mathrm{a}}\left(\mathrm{s}^{-1}\right)$ \\
\hline $\begin{array}{l}\text { Glycine methyl } \\
\text { ester }\end{array}$ & $\begin{array}{l}4.2 \\
4.4 \\
4.6 \\
4.8\end{array}$ & $\begin{array}{l}2.06 \\
3.28 \\
5.19 \\
8.23\end{array}$ & $\begin{array}{l}2.39(0.04) \\
3.19(0.02) \\
4.03(0.03) \\
5.80(0.05)\end{array}$ \\
\hline & pH & $10^{5}\left[\mathrm{OH}^{-}\right]$ & $10^{4} \mathrm{k}_{\text {obs }}\left(\mathrm{s}^{-1}\right)$ \\
\hline $\begin{array}{l}\text { Methionine } \\
\text { methyl ester }\end{array}$ & $\begin{array}{l}8.8 \\
9.0 \\
9.2 \\
9.4\end{array}$ & $\begin{array}{l}0.82 \\
1.30 \\
2.06 \\
3.27\end{array}$ & $\begin{array}{l}4.11(0.06) \\
5.46(0.08) \\
7.14(0.14) \\
8.47(0.18)\end{array}$ \\
\hline $\begin{array}{l}\text { Histidine methyl } \\
\text { ester }\end{array}$ & $\begin{array}{l}8.8 \\
9.0 \\
9.2 \\
9.4\end{array}$ & $\begin{array}{l}0.82 \\
1.30 \\
2.06 \\
3.27\end{array}$ & $\begin{array}{l}2.34(0.02) \\
4.07(0.07) \\
5.25(0.05) \\
7.24(0.08)\end{array}$ \\
\hline
\end{tabular}
stable as once the complex is formed the hydrolysis of the ester starts.

Table 1. Kinetics of hydrolysis of coordinated amino acid ester in aqueous solution at $25^{\circ} \mathrm{C}$.

${ }^{\mathrm{a}}$ standard deviations are given in parentheses

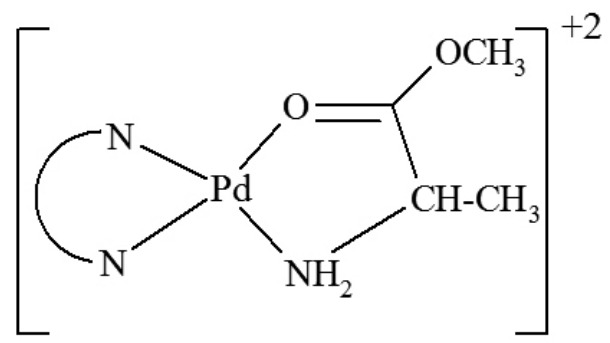

The formation of bidentate ester complexes with both copper(II) and cobalt(II) leads to rate accelerations ${ }^{27,28}$ of $10^{5}-10^{6}$ and the situation with palladium(II) appears to be similar. The base hydrolysis of coordinated histidine and methionine esters was studied in the $\mathrm{pH}$ range 9-10. Throughout this $\mathrm{pH}$ range the reaction shows a first-order dependence on the hydroxide ion concentration. The relative catalysis ratio $(\mathrm{C})$ observed with $\mathrm{L}$-methylmethionate $(\mathrm{L}-\mathrm{MethOMe})\left[k_{\mathrm{OH}} / k_{\mathrm{OH}}\right.$ ester $\left.=22.85\right]$ and methyl-L-histidinate $(\mathrm{L}-\mathrm{HisOMe})\left[k_{\mathrm{OH}} /\right.$ $\left.k_{\mathrm{OH}}{ }^{\text {ester }}=30.64\right]$, table (1), suggests that in these cases the alkoxycarbonyl group is not bonded to the metal ion.<smiles></smiles>

II<smiles>CC(=O)C1CC[SH](C)[P@]2(CCCN2)N1</smiles>

III
L-MethOMe complex is expected to have the structure (II), in which the donor atoms are thiolato-sulphur and the a-amino group. A similar situation (III) is likely with L-hisOMe, where the a-amino group and the pyridine nitrogen of the imidazole ring act as donors. Previous studies have shown that the formation of such complexes with non-bonded or pendant ester groups

\begin{tabular}{|c|c|c|c|c|}
\hline System & $\boldsymbol{k}_{\mathrm{OH}}$ & $k_{\mathrm{H} 2 \mathrm{O}}$ & $\mathrm{k}_{\mathrm{OH}}{ }^{\text {ester(a) }}$ & $\underset{\mathrm{k}_{\mathrm{OH}}^{\text {(ester) }}}{\mathrm{k}_{\mathrm{H}} / \mathrm{I}}$ \\
\hline Glycine methyl ester & $5.42 \times 10^{5}$ & $9.76 \times 10^{-6}$ & 1.28 & $4.23 \times 10^{5}$ \\
\hline $\begin{array}{l}\text { Methionine } \\
\text { methyl ester }\end{array}$ & 17.6 & $5.48 \times 10^{-6}$ & 0.77 & 22.85 \\
\hline Histidine methyl ester & 19.0 & $2.14 \times 10^{-6}$ & 0.62 & 30.64 \\
\hline
\end{tabular}
leads to only relatively small rate increases ${ }^{27}$.

Table 2. Rate constant $\left(\mathrm{k} / \mathrm{dm}^{3} \mathrm{~mol}^{-1} \mathrm{~s}^{-1}\right)$ for base hydrolysis of amino acid esters and their complexes at $25^{\circ} \mathrm{C}$ in aqueous solution.

(a) Ref. (20), (21)

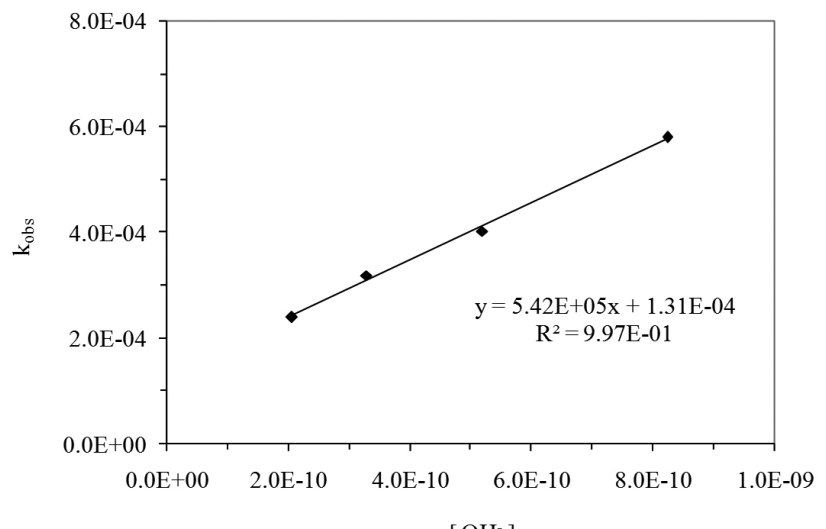

$\left[\mathrm{OH}^{-}\right]$

Fig. 1. Plot of $\mathrm{k}_{\mathrm{obs}}$ vs. $\left[\mathrm{OH}^{-}\right]$for the hydrolysis of coordinated glycine methyl ester at $25^{\circ} \mathrm{C}$.

The relative catalysis ratio at $25^{\circ} \mathrm{C}$ for the base hydrolysis of the glycine methyl ester incorporated in $[\mathrm{Pd}(\mathrm{en}) \mathrm{L}]^{2+}$ is $3.81 \times 10^{4} .{ }^{18}$ The corresponding value for $[\mathrm{Pd}(\mathrm{DHP}) \mathrm{L}]^{2+}\left(4.23 \times 10^{5}\right)$ is higher than that of $[\mathrm{Pd}(\mathrm{en}) \mathrm{L}]^{2+}$. This may be explained on the premise that the $[\mathrm{Pd}(\mathrm{DHP}) \mathrm{L}]^{2+}$ complex is involving formation of more enlarged six-membered chelate ring and associated with increase of electrophilicity of the Pd(II) centre. The electrophilicity is one of the factors determining the donor-acceptor interaction between the ester and $\mathrm{Pd}(\mathrm{II})$ ion, the complex which binds the ester more tightly, would withdraw the most electron density from the ester making it more susceptible to $\mathrm{OH}^{-}$attack. This will lead to increase of the respective catalysis ratio. 


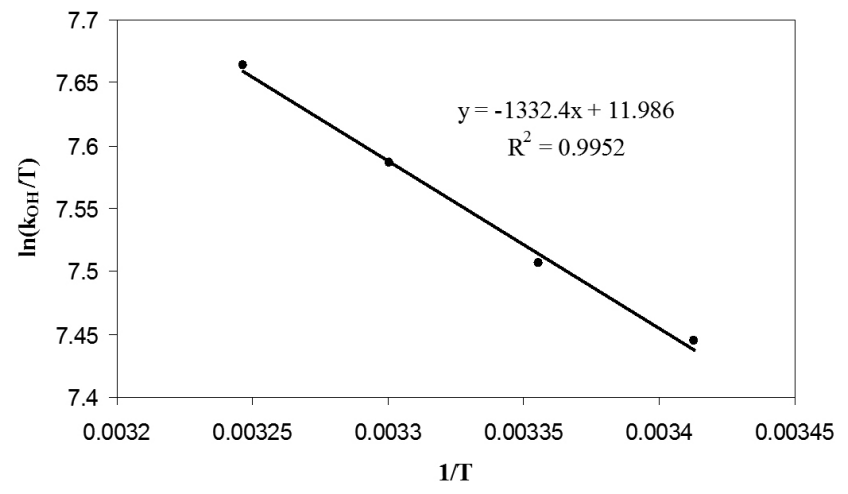

Fig. 2. Plot of $\ln \mathrm{k}_{\mathrm{OH}} / \mathrm{T}$ vs. 1/T for the hydrolysis of coordinated glycine methyl ester.

Table 3. Rate constant $\left(\mathrm{k} / \mathrm{dm}^{3} \mathrm{~mol}^{-1} \mathrm{~s}^{-1}\right)$ for base hydrolysis of coordinated Glycine methyl ester at different temperatures in aqueous solution.

\begin{tabular}{|c|c|c|}
\hline Temp. ${ }^{\circ} \mathbf{C}$ & $\boldsymbol{k}_{\text {OH }}$ & $\boldsymbol{k}_{\text {H2o }}$ \\
\hline 20 & $5.01 \times 10^{5}$ & $2.25 \times 10^{-6}$ \\
25 & $5.42 \times 10^{5}$ & $2.36 \times 10^{-6}$ \\
30 & $5.97 \times 10^{5}$ & $2.48 \times 10^{-6}$ \\
35 & $6.56 \times 10^{5}$ & $2.60 \times 10^{-6}$ \\
\hline
\end{tabular}

The activation parameters $\left(\mathrm{DH}^{\sharp}\right.$ and $\mathrm{DS}^{ \pm}$) were determined for the hydrolysis of coordinated glycine methyl ester from the temperature dependence of the rates in Table 3. The activation parameters were obtained using the Eyring plot of $\left(\ln k_{\mathrm{OH}} / \mathrm{T}\right)$ versus $1 / \mathrm{T}$, Fig. (2), from which the values $\mathrm{DH}^{*}=11.07 \mathrm{kJmol}^{-1}, \mathrm{DS}^{ \pm}=-99.60 \mathrm{JK}^{-1} \mathrm{~mol}^{-1}$ were calculated ${ }^{25}$. For the base hydrolysis of free glycinemethyl ester the activation parameters were found ${ }^{10}$ to be $\mathrm{DH}^{\#}=39.7 \mathrm{kJmol}^{-1}$ and $\mathrm{DS}^{\#}=-117 \mathrm{JK}^{-1} \mathrm{~mol}^{-1}$. The enhanced rate for base hydrolysis of the ester incorporated in the complex $[\mathrm{Pd}(\mathrm{DHP}) \mathrm{L}]^{2+}$ is therefore due to a decreased $\mathrm{DH}^{\sharp}$ and an increased $\mathrm{DS}^{ \pm}$implies desolvation between the ground and transition states and is indicative of a mechanism involving nucleophilic attack by external $\mathrm{OH}^{-}$on the complexed ester group.

\section{CONCLUSION}

The hydrolysis of glycine methyl ester is catalyzed by $\left[\mathrm{Pd}(\mathrm{DHP})\left(\mathrm{H}_{2} \mathrm{O}\right)_{2}\right]^{2+}$ complex with catalysis ratio $\mathrm{C}=4.23 \times 10^{5}$. The catalytic effect is due to a direct interaction between Pd(II) and the alkoxycarbonyl group of the ester species. However, the hydrolysis of histidine and methionine methyl esters is not significantly catalyzed. The relative small catalysis-ratio values suggest that in these cases the alkoxycarbonyl group is not bonded to the metal ion . The activation parameters for the hydrolysis of coordinated glycine methyl ester were determined.

\section{REFERENCES}

1. W.N. Lipscomb, Acc. Chem. Res 3, 81, (1970)

2. M.J. Pesando, Biochemistry, 14, 681, (1975)

3. T.W. Reid, I.B. Wilson, in Boyer PD (Ed.) The Enzymes, $3^{\text {rd }}$ edit., Academic Press. New York, 1971.

4. D.S. Auld ,in M.I. Page and A. Williams (Eds.) Enzyme Mechanisms. The Royal Society of Chemistry, London, 1987. 5. D.W. Christianson, W.N. Lipscomb, Acc. Chem. Res., 22, 62 (1989).

6. J.M. Harrowfield, V. Morris, A.M. Sageson, J. Am. Chem. Soc., 98, $7282,(1976)$

7. J.E. Coleman, J.F. Chlebowski ,in L.G. Marzilli (Eds) Advances in Inorganic Chemistry, Elsevier, New York, (1979).

8. R. Jairam, M.L. Lau, J. Adorante, P.G. Potvin, J. Inorg. Biochem., 84, $113,(2001)$.

9. X. Kou, X. Meng, J. Xie, Z. Zeng, Transition Met. Chem., 28, 777, (2003).

10. J. Xia, S. Li, Y. Shi, K. Yu, W. Tong, J. Chem. Soc., Dalton Trans., 2109 (2001).

11. X. Su, H. Sun, Z. Zhou, H. Lin, L. Chen, S. Zhu, Y. Chen, Polyhedron. 20, 91, (2001)

12. M.R. Shehata, M. M. Shoukry, F.M.H. Nasr, R. van Eldik, Dalton Trans., $779,(2008)$.

13. M.R. Shehata, M M. Shoukry, F.H. Abdel-Shakour, R. van Eldik, Eur. J. Chem., 3912, (2009).

14. M.M.A. Mohamed, A. A. Shoukry, M. M. Shoukry, International journal of chemical kinetics, 737, (2006).

15. M.M.A. Mohamed, M.M. Shoukry, Polyhedron, 21, 167, (2002). 16. A.A. El-Sherif, M.M. Shoukry, Inorg. Chim. Acta, 360, 473, (2007).

17. M.M. Shoukry, E.M. Khairy, A. Saeed, Transition Metal Chem., 12, 315, (1987).

18. R.W. Hay, P. Banerjee, J. Chem. Soc. Dalton. Trans., 362, (1981).

19. R.G. Bates, Determination of $p H$-Theory and Practice, $2^{\text {ndedit., Wiley }}$ Interscience, New York, 1975.

20. R.W. Hay, A.K. Basak, J. Chem. Soc. Dalton. Trans., 1819 (1982).

21. R.W. Hay, P.J. Morris, in "metal Ions in Biological Systems", Ed., H. Sigel Marcel Dekker, New York, 5, 173 (1976).

22. OLIS KIFET, Olis inc. Borgart GA, 19, (1993).

23. A.A. Shoukry, T. Rau, M.M. Shoukry, R. van Eldik, J. Chem. Soc. Dalton Trans., 3105 (1998).

24. C.W. Davis, J. Chem. Soc., 2093, (1936).

25. R.A. Robinson, R.H. Stokes, electrolyte solutions, $2^{\text {nd }}$ edn., Butterworths, London, 1979

26. R.W. Hay, P. Banerjee, J. Chem. Soc. Dalton. Trans., 362 (1981).

27. R.W. Hay, L.J. Porter, J. Chem. Soc. B, 1261, (1967).

28. R.W. Hay, A.K. Basak, J. Chem. Soc. Dalton Trans., 1819, (1982). 